Elif Börekci*, Mahmut Kılıç, Zeynep Ozan, Hasan Börekci, Tekin Yıldırım, Yeşim Göçmen and Hatice Baş

\title{
Increased vitamin D binding protein levels are associated with irritable bowel syndrome
}

\section{[Artmış D vitamini bağlayıcı protein seviyeleri İrritabl barsak sendromu ile ilişkilidir]}

https://doi.org/10.1515/tjb-2020-0305

Received June 26, 2020; accepted March 24, 2021;

published online April 15, 2021

\section{Abstract}

Objectives: There is no reliable and valid biomarker to identify Irritable bowel syndrome (IBS) and its subtypes. The aim of this study is to explore potential serum biomarkers that may be associated with IBS subtypes, particularly in the vitamin D pathway.

Methods: The study population comprised 75 IBS patients and 79 controls. Patients divided into IBS subtypes. Routine biochemical parameters, 25-OH-vitamin D, vitamin D binding protein (VDBP) and vitamin D receptor (VDR) serum levels were compared between IBS subtypes and controls. Factors related to IBS subtypes were examined by multivariate logistic regression analysis.

Results: Vitamin D levels were lower; VDBP and VDR were higher in all IBS patients than in controls $(\mathrm{p}<0.001 ; 0.047$ and 0.029, respectively). According to logistic regression

\footnotetext{
*Corresponding author: Elif Börekci, MD, Department of Internal Medicine, Celal Bayar University Faculty of Medicine, Manisa, Turkey, Phone: +90 (0) 5056431172, E-mail: drelifg@hotmail.com. https:// orcid.org/0000-0003-2037-2947

Mahmut Kılıç, Department of Public Health, Bozok University Faculty of Medicine, Yozgat, Turkey

Zeynep Ozan and Tekin Yıldırım, Department of Internal Medicine, Bozok University Faculty of Medicine, Yozgat, Turkey Hasan Börekci, Department of General Surgery, Bozok University Faculty of Medicine, Yozgat, Turkey

Yeşim Göçmen, Department of Biochemistry, Bozok University Faculty of Medicine, Yozgat, Turkey

Hatice Baş, Department of Biology, Bozok University Faculty of Arts and Science, Yozgat, Turkey
}

analysis, VDBP was a disease-related parameter as much as vitamin D in all IBS subtypes. C-reactive protein (CRP) and erythrocyte sedimentation rate (ESR) were higher especially in diarrhea-dominant IBS (IBS-D) $(\mathrm{p}=0.041$; 0.046 ) and vitamin B12 were significantly lower in constipation-dominant IBS (IBS-C) $(\mathrm{p}=0.001)$.

Conclusions: Increased VDBP levels were associated with all IBS subtypes. Patients, especially in IBS-D, had higher serum levels of VDBP, CRP and ESR. Vitamin B12 deficiency, which we consider as a result of the disease, was more common in IBS-C.

Keywords: biochemical markers; IBS subtypes; inflammation; irritable bowel syndrome; vitamin D; vitamin D binding protein; vitamin $\mathrm{D}$ receptor

\section{Öz}

Amaç: İrritabl barsak sendromu (IBS) ve alt tiplerini tanımlamak için güvenilir ve geçerli bir biyobelirteç yoktur. Bu çalışmanın amacı, özellikle D vitamini yolağında IBS alt tipleri ile ilişkili olabilecek potansiyel serum biyobelirteçlerini araştırmaktır.

Gereç ve Yöntem: Çalışma popülasyonu 75 IBS hastası ve 79 kontrolden oluşmuştur. Hastalar IBS alt tiplerine ayrilmıştır. IBS alt tipleri ve kontroller arasinda rutin biyokimyasal parametreler, 25-OH-vitamin D, vitamin D bağlayıcı protein (VDBP) ve vitamin D reseptörü (VDR) serum seviyeleri karşılaştırılmıştır. IBS alt tipleri ile ilişkili faktörler çok değişkenli lojistik regresyon analizi ile incelenmiştir.

Bulgular: Tüm IBS hastalarında kontrollere göre D vitamini seviyeleri daha düşük, VDBP ve VDR seviyeleri daha yüksekti (sırasıyla $\mathrm{p}<0.001 ; 0.047$ ve 0.029). Lojistik regresyon analizine göre VDBP, tüm IBS alt tiplerinde D 
vitamini kadar hastalıkla ilişkili bir parametre idi. C-reaktif protein (CRP) ve eritrosit sedimentasyon hızı (ESR), özellikle ishal baskın IBS'de (IBS-D) daha yüksekti ( $\mathrm{p}=0.041$; 0.046) ve vitamin B12, kabızlık baskın IBS'de (IBS-C) anlamlı olarak daha düşüktü ( $\mathrm{p}=0.001)$.

Sonuçlar: Artmış VDBP seviyeleri tüm IBS alt tipleri ile ilişkiliydi. Özellikle IBS-D'deki hastalar daha yüksek VDBP, CRP ve ESR seviyelerine sahipti. Hastalığın sonucu olarak gördüğümüz B12 vitamini eksikliği IBS-C'de daha sık idi.

Anahtar kelimeler: irritabl barsak sendromu; IBS alt tipleri; D vitamini; D vitamini bağlayıcı protein; D vitamini reseptörü; inflamasyon; biyokimyasal belirteçler

\section{Introduction}

Irritable bowel syndrome (IBS) is a very frequent functional disorder characterized by irregular bowel movements and abdominal discomfort [1]. It is stated that the incidence can be up to $45 \%$ in some studies [2]. Today, Rome IV diagnostic criteria are used in the clinical diagnosis of IBS patients. To aid clinical management, IBS patients are often classified into subtypes [3].

Although it is common in the world; the etiopathogenesis of the disease has not been clearly clarified [4]. It has been documented that irritable bowel syndrome may be a chronic inflammatory disease. Chronic, low-grade, subclinical inflammation is thought to cause the disease process and maintain the symptoms of IBS [5]. However, there is no reliable and valid biomarker for the recognition of IBS and its subtypes. Also, our knowledge of why different IBS subtypes occur is not clear [6].

According to recent studies, vitamin D deficiency is common in individuals with IBS $[7,8]$. Vitamin D is a hormone that plays a role in regulating calcium metabolism and has an important role in controlling the inflammatory system [9]. Vitamin D binding protein (VDBP) is another important component in vitamin D pathway. In addition to being the main transport protein of vitamin $\mathrm{D}$ and playing an important role in the bioavailability of vitamin D; it also has immunomodulatory and antiinflammatory functions and has been recognized as a novel marker of inflammation [10,11]. Vitamin D receptor is common in intestinal epithelial cells because it mediates the biological activity of vitamin D [12]. It plays an important role in ensuring mucosal barrier homeostasis [13]. Thus, vitamin D and its receptor can positively affect altered gut function [14].
Many autoimmune and inflammatory diseases have been associated with vitamin D deficiency [9]. Although there are studies indicating that vitamin D deficiency is common in IBS; there are no studies associating serum vitamin D, VDBP and vitamin D receptor (VDR) receptor and IBS subtypes. 25-OH-vitamin D is the best indicator of vitamin D status, so it is the most commonly studied form of vitamin D [15]. Our aim in this work is to explore whether there is a difference between IBS subtypes in terms of biochemical parameters such as $25-\mathrm{OH}$-vitamin D, VDBP, VDR serum levels and also to identify a new potential biochemical parameter that can be associated with IBS.

\section{Materials and methods}

\section{Study population}

This study was performed in line with the principles of the Declaration of Helsinki. Seventy-five IBS patients defined according to Roma IV diagnostic criteria and 79 healthy controls without any clinical evidence or symptoms of IBS were included in the study. Colonoscopic examinations were normal in all patients. Subjects with malignancy, inflammatory or autoimmune disease, organ failure, endocrinologic diseases, pregnancy and those who use drugs effective on vitamin D metabolism (vitamin D supplements, antiretroviral drugs or rifampicin, etc.) or drugs that alter gastrointestinal motility and those with alcohol and smoking habits were excluded from the study. Age and gender of the participants were obtained and body mass indexes (BMI) were calculated.

Newly diagnosed 75 IBS patients were grouped according to IBS subtypes such as constipation-dominant (IBS-C), diarrhea-dominant (IBS-D), mix type (IBS-M). IBS subtypes were determined according to the dominant bowel pattern using the Bristol Stool Form Scale. In more than $25 \%$ of the time; patients having hard or lumpy stools were grouped as constipation-dominant IBS (IBS-C), patients having loose or watery stools as diarrhea-dominant IBS (IBS-D), those having a mixed pattern alternating diarrhea and constipation as mix type IBS (IBS-M) [3].

Serum samples of controls and grouped IBS patients were analyzed and compared in terms of routine biochemical markers and 25-OH-vitamin D, VDBP and VDR levels. Taking the control group as the reference group, parameters related to IBS subtypes were examined by multivariate logistic regression analysis. Also correlation analysis was made separately for patient and control groups.

\section{Biochemical analysis}

Venous blood samples were collected from each subject after at least $8 \mathrm{~h}$ of fasting and in the same season so that serum vitamin D levels were not affected by seasonal variations. Collected blood samples were centrifuged at 3,000 rpm for $10 \mathrm{~min}$. Then, the supernatant was removed and kept frozen at $-70{ }^{\circ} \mathrm{C}$. Serum calcium, phosphorus, C-reactive protein (CRP), alanine aminotransferase (ALT), aspartate aminotransferase (AST), creatinine, albumin, and lipid concentrations were measured using assay kits (Abbott ${ }^{\circledR}$, IL, USA) with an 
autoanalyzer (Aeroset ${ }^{\circledR}$, Abbott $^{\circledR}$, IL, USA). Vitamin B12 and thyroidstimulating hormone (TSH) were analyzed by the electrochemiluminescence immunoassay (ECLIA) using commercial kits (Abbott Laboratories) suitable for the autoanalyzer (Architect i2000; Abbott Laboratories, Abbott Park, IL, USA).

Elisa Kits for the measurement of 25-OH-vitamin D (Elabscience, USA), VDBP (Elabscience, USA) and VDR (Cusabio, Wuhan, China) levels were used. The detectable ranges were $3.13-200 \mathrm{ng} / \mathrm{mL}$ for 25-OH-vitamin D, 3.91-250 ng/mL for VDBP and 6.25-400 pg/mL for VDR.

\section{Statistical analysis}

For the analysis of the data, IBM SPSS Statistics Standard Concurrent User V 25 (Authorization Code: e31d836848b0a60e5756) was used. Kolmogorov-Smirnov/Shapiro-Wilk tests were used to examine the normal distribution suitability of the variables. Descriptive statistics were presented as mean $( \pm)$ standard deviation, frequency distribution and percentage.

The one-way analysis of variance (ANOVA) is used to determine whether there are any statistically significant differences between the means of independent groups and the significance of the difference between the four groups was evaluated by posthoc tests. Since the number of persons in both the IBS-D ( $n=13)$ and IBS-M $(n=13)$ groups was very small, these two groups were combined (other types) and included in multinomial regression analysis as three groups (control, IBS-C and other types).

Multinomial logistic regression analysis of IBS related parameters was performed by using Forward-Stepwise method. Variables that were found to be significant at approximately $p \leq 0.1$ level in the ANOVA test were included in the regression model. Gender was categorical variable that was converting to dummy variable. The control group was taken as the reference group for comparison. Results for $\mathrm{p}<0.05$ were considered statistically significant. Also, correlation analysis was made separately for patient and control groups.

\section{Results}

Among the IBS cases, vitamin D deficiency $(<20 \mathrm{ng} / \mathrm{mL})$ in 46 patients; vitamin D insufficiency $(20-29 \mathrm{ng} / \mathrm{mL})$ in 15 patients; vitamin D sufficiency ( $\geq 30 \mathrm{ng} / \mathrm{mL}$ ) in 14 patients were detected. Mean level of vitamin D in IBS patients was $21 \pm 12 \mathrm{ng} / \mathrm{mL}$; in the control group was $42 \pm 20 \mathrm{ng} / \mathrm{mL}$. Serum VDBP and VDR levels were higher in all of IBS patients than healthy controls $(\mathrm{p}=0.047$ and 0.029 , respectively), while vitamin D levels were lower $(\mathrm{p}<0.001)$.

When IBS patients were grouped according to IBS subtypes, there were $49(66 \%)$ in the constipationdominant group, $13(17 \%)$ in the diarrhea-dominant group and $13(17 \%)$ in the mixed-type IBS group. The demographic and laboratory data of IBS subtypes and controls were summarized in Table 1.
In the posthoc Tumhane test for Vitamin D, the difference between the IBS subtypes and the control group was statistically significant $(\mathrm{p}<0.01)$, while the difference between the IBS subtypes was not significant $(p>0.05)$. In the posthoc Benferroni test for vitamin B12, the difference between the IBS-C subtype and the control group was statistically significant $(\mathrm{p}<0.01)$, but the difference between the control group and the IBS-D and IBS-M subtypes was not significant ( $p>0.05)$ (Table 1$)$.

Since IBS-D $(n=13)$ and IBS-M $(n=13)$ groups were very small, these two groups were combined as "other subtypes of IBS" (Table 2) and included in multinominal regression analysis as three groups (control, IBS-C and other subtypes).

Multinomial logistic regression analysis of IBS related parameters was performed by using Forward-Stepwise method. According to multinomial logistic regression analysis; in the IBS-C subtype, VDBP and alanine aminotransferase (ALT) levels were higher than in the control group ( $\mathrm{p}<0.001$ and $\mathrm{p}=0.008$, respectively), while vitamin $\mathrm{D}$ and vitamin B12 were lower ( $\mathrm{p}<0.001$ and $\mathrm{p}=0.018$, respectively). In the "other subtypes" of IBS, while VDBP and C-reactive protein (CRP) were higher than in the control group ( $\mathrm{p}<0.001$ and $\mathrm{p}=0.036)$, vitamin $\mathrm{D}$ was lower $(\mathrm{p}<0.001)$ and Vitamin B12 was not significant $(\mathrm{p}>0.05)$. VDBP was determined as a disease-related parameter as much as Vitamin D in both IBS-C and other IBS subtypes $(\mathrm{p}<0.001)$. However; gender, age, BMI, white blood cell (WBC), low density lipoprotein cholesterol (LDL-C), platelet, phosphorus and erythrocyte sedimentation rate (ESR) included in the multinomial regression analysis (forward stepwise) were not statistically significant ( $>>0.05$ ) (Table 3).

In the correlation analysis made separately for patient and control groups; while there was a positive correlation between vitamin $\mathrm{D}$ and VDBP levels in healthy individuals $(\mathrm{r}=0.5, \mathrm{p}<0.001)$, no correlation $(\mathrm{r}=-0.10, \mathrm{p}>0.05)$ was found in IBS patients (Tables 4 and 5 ).

\section{Discussion}

In our study; VDBP was detected as a biochemical parameter associated with IBS as much as vitamin D. In the multinomial logistic regression analysis of variables that may be associated with IBS; vitamin D and VDBP have been found as associated parameters with IBS-C and other subtypes of IBS. The relationship between high serum VDBP levels and IBS subtypes was demonstrated for the first time with this study. High VDBP levels have been associated with inflammatory conditions [10, 11]. Therefore, our results also support that IBS is an inflammatory 
Table 1: Demographic and laboratory data for IBS patients and control group.

\begin{tabular}{|c|c|c|c|c|c|c|c|c|c|}
\hline \multirow[t]{3}{*}{ Variables } & \multicolumn{8}{|c|}{ IBS types \& control } & \multirow[t]{3}{*}{ p-Value } \\
\hline & \multicolumn{2}{|c|}{ Control $(n=79)$} & \multicolumn{2}{|c|}{ Constipation $(n=49)$} & \multicolumn{2}{|c|}{ Diarrhea $(n=13)$} & \multicolumn{2}{|c|}{$\operatorname{Mix}(n=13)$} & \\
\hline & Mean & (SD) & Mean & (SD) & Mean & (SD) & Mean & (SD) & \\
\hline Age, year & 40.84 & (10.81) & 43.14 & (14.18) & 39.85 & $(10.22)$ & 46.69 & (12.93) & 0.321 \\
\hline $\mathrm{BMI}, \mathrm{kg} / \mathrm{m}^{2}$ & 28.78 & $(3.81)$ & 29.37 & $(4.14)$ & 26.16 & $(3.36)$ & 28.10 & (3.11) & 0.061 \\
\hline Vitamin $\mathrm{D}, \mathrm{ng} / \mathrm{mL}$ & 42.00 & (20.76) & 21.47 & (11.12) & 24.71 & (18.49) & 16.77 & (8.71) & $<0.01$ \\
\hline VDBP, $\mathrm{ng} / \mathrm{mL}$ & 40.20 & $(7.62)$ & 41.84 & $(4.93)$ & 42.47 & $(5.22)$ & 43.79 & $(4.75)$ & 0.183 \\
\hline VDR, pg/mL & 67.38 & (23.14) & 75.69 & $(23.30)$ & 77.88 & (15.65) & 72.61 & $(27.79)$ & 0.167 \\
\hline Albumin, $\mathrm{mg} / \mathrm{dL}$ & 4.21 & $(0.32)$ & 4.23 & $(0.35)$ & 4.11 & $(0.17)$ & 4.23 & $(0.24)$ & 0.676 \\
\hline Calcium, mg/dL & 9.39 & $(0.45)$ & 9.44 & $(0.61)$ & 9.36 & $(0.45)$ & 9.51 & $(0.62)$ & 0.860 \\
\hline WBC, $10^{3} / \mathrm{mm}^{3}$ & 7.71 & (1.50) & 7.54 & (1.63) & 8.23 & (1.49) & 8.47 & (2.13) & 0.199 \\
\hline Hematocrit, \% & 42.35 & $(4.63)$ & 42.79 & $(4.87)$ & 42.22 & (3.56) & 42.58 & (3.15) & 0.952 \\
\hline Platelet, $10^{3} / \mathrm{mm}^{3}$ & 266.57 & $(67.69)$ & 291.08 & $(72.56)$ & 260.85 & $(52.30)$ & 284.77 & $(47.64)$ & 0.181 \\
\hline Creatinine, $\mathrm{mg} / \mathrm{dL}$ & 0.73 & $(0.17)$ & 0.76 & $(0.12)$ & 0.73 & $(0.08)$ & 0.72 & $(0.11)$ & 0.569 \\
\hline AST, IU/L & 18.56 & $(5.55)$ & 21.39 & (10.94) & 17.00 & $(3.44)$ & 20.77 & $(5.95)$ & 0.118 \\
\hline ALT, IU/L & 18.29 & (8.04) & 24.43 & (19.31) & 18.92 & $(6.60)$ & 22.62 & $(9.46)$ & $<0.05$ \\
\hline Total cholesterol, mg/dL & 203.89 & (38.73) & 193.24 & $(38.55)$ & 194.08 & $(31.62)$ & 198.54 & $(54.17)$ & 0.490 \\
\hline $\mathrm{HDL}, \mathrm{mg} / \mathrm{dL}$ & 45.93 & $(8.61)$ & 47.88 & $(7.62)$ & 49.45 & $(7.20)$ & 45.92 & $(7.47)$ & 0.348 \\
\hline $\mathrm{LDL}, \mathrm{mg} / \mathrm{dL}$ & 127.85 & $(29.85)$ & 114.58 & (31.46) & 125.20 & (26.89) & 119.49 & $(40.62)$ & 0.132 \\
\hline Triglycerides, mg/dL & 145.18 & $(74.20)$ & 159.29 & (142.19) & 112.46 & (48.73) & 150.77 & $(75.70)$ & 0.507 \\
\hline Vitamin B12, ng/L & 378.33 & $(180.80)$ & 275.35 & (124.66) & 322.69 & (115.11) & 316.23 & (148.75) & $<0.01$ \\
\hline $\mathrm{TSH}, \mu \mathrm{IU} / \mathrm{L}$ & 1.95 & $(2.06)$ & 2.00 & (1.87) & 1.46 & $(1.62)$ & 1.46 & $(0.77)$ & 0.662 \\
\hline Phosphorus, mg/dL & 3.66 & $(0.73)$ & 3.46 & $(0.72)$ & 3.55 & (1.08) & 2.95 & $(0.64)$ & $<0.05$ \\
\hline $\mathrm{CRP}, \mathrm{mg} / \mathrm{L}$ & 3.73 & (6.95) & 3.22 & $(2.99)$ & 7.74 & (12.88) & 5.16 & $(5.58)$ & 0.084 \\
\hline $\mathrm{ESR}, \mathrm{mm}$ & 12.15 & $(8.62)$ & 14.94 & (9.29) & 16.92 & (10.67) & 16.77 & (7.67) & 0.095 \\
\hline Female n, \% & 45 & (57) & 32 & (65) & 9 & (69) & 12 & (92) & \\
\hline Male n, \% & 34 & (43) & 17 & (35) & 4 & (31) & 1 & (8) & \\
\hline
\end{tabular}

Values are expressed as $\mathrm{n}(\%)$ and mean (SD). BMI, body mass index; WBC, white blood cell; AST, aspartate aminotransferase; ALT, alanine aminotransferase; HDL; high density lipoprotein; LDL, low density lipoprotein; TSH, thyroid-stimulating hormone; CRP, C-reactive protein; VDBP, vitamin D binding protein; VDR, vitamin D receptor; ESR, Erythrocyte Sedimentation Rate. Bold variables are significant $p<0.05$ by ANOVA test.

disorder along with vitamin D deficiency. Patients, especially in the IBS-D subtype, had higher serum levels of inflammatory markers, VDBP, CRP and ESR. In addition, vitamin B12 deficiency, which we consider as a result of the disease, was more common in IBS-C subtype.

There is no reliable and valid biomarker for the recognition of IBS and its subtypes [6]. Therefore, the diagnosis is made according to the Roma criteria based on symptoms. According to stool consistency, IBS patients are classified into subtypes [3]. In IBS treatment, priority is given to the use of specific therapies that target the dominant symptoms. There are a wide variety of treatment approaches available. Lifestyle changes, dietary changes, pharmacological therapies, psychological strategies or a combination of interventions can be used to optimize treatment for each patient [16]. Medical management of symptoms and clinical studies evaluating pharmacological treatments for IBS are increasingly focused to the IBS subtype, emphasizing the importance of reliably segregating patients [17].
Studies in the literature have shown that Vitamin D replacement has beneficial effects especially in IBS-D patients. A case report of Sprake et al. showed a possible treatment response to vitamin $\mathrm{D}$ replacement in active IBS-D [18]. In another study, it was detected that IL-6 level is significantly higher in IBS-D compared to control [19]. In this study conducted to see if there is a difference in terms of biochemical parameters between IBS subtypes and controls; whereas we found that Vitamin D was lower and VDR and VDBP were higher in the serum of IBS patients compared to in non-IBS subjects; we did not find any significant difference in terms of Vitamin D, VDBP and VDR among IBS subtypes.

Inflammation in the gastrointestinal tract is an important part of IBS pathogenesis [5, 20]. In one study in the literature; ESR has been proposed as a potential marker for IBS. In the study, it was found that ESR was higher in IBS patients with more intestinal symptoms and emotional disorders. However, there was no significant relationship between ESR and disease severity [21]. In another study, it 
Table 2: Demographic and laboratory data for IBS patients and control group.

\begin{tabular}{|c|c|c|c|c|c|c|c|}
\hline \multirow[t]{3}{*}{ Variables } & \multicolumn{6}{|c|}{ IBS types \& control } & \multirow[t]{3}{*}{ p-Value } \\
\hline & \multicolumn{2}{|c|}{ Control $(n=79)$} & \multicolumn{2}{|c|}{ Constipation $(n=49)$} & \multicolumn{2}{|c|}{ Other types $(n=26)$} & \\
\hline & Mean & (SD) & Mean & (SD) & Mean & (SD) & \\
\hline Age, year & 40.84 & (10.81) & 43.14 & (14.18) & 43.27 & (11.94) & 0.488 \\
\hline BMI, $\mathrm{kg} / \mathrm{m}^{2}$ & 28.78 & $(3.81)$ & 29.37 & (4.14) & 27.13 & (3.32) & 0.057 \\
\hline Vitamin D, ng/mL & 42.00 & (20.76) & 21.47 & (11.12) & 20.74 & (14.73) & $<0.001$ \\
\hline VDBP, $\mathrm{ng} / \mathrm{mL}$ & 40.20 & $(7.62)$ & 41.84 & $(4.93)$ & 43.13 & $(4.93)$ & 0.100 \\
\hline VDR, $\mathrm{pg} / \mathrm{mL}$ & 67.38 & (23.14) & 75.69 & $(23.30)$ & 75.25 & $(22.26)$ & 0.093 \\
\hline Albumin, $\mathrm{mg} / \mathrm{dL}$ & 4.21 & $(0.32)$ & 4.23 & $(0.35)$ & 4.17 & $(0.21)$ & 0.758 \\
\hline Calcium, mg/dL & 9.39 & $(0.45)$ & 9.44 & $(0.61)$ & 9.43 & $(0.54)$ & 0.886 \\
\hline WBC, $10^{3} / \mathrm{mm}^{3}$ & 7.71 & $(1.50)$ & 7.54 & (1.63) & 8.35 & (1.81) & 0.104 \\
\hline Hematocrit, \% & 42.35 & $(4.63)$ & 42.79 & $(4.87)$ & 42.40 & (3.30) & 0.860 \\
\hline Platelet, $10^{3} / \mathrm{mm}^{3}$ & 266.57 & (67.69) & 291.08 & (72.56) & 272.81 & (50.51) & 0.131 \\
\hline Creatinine, $\mathrm{mg} / \mathrm{dL}$ & 0.73 & $(0.17)$ & 0.76 & $(0.12)$ & 0.72 & $(0.09)$ & 0.151 \\
\hline AST, IU/L & 18.56 & $(5.55)$ & 21.39 & (10.94) & 18.88 & $(5.13)$ & 0.116 \\
\hline ALT, IU/L & 18.29 & (8.04) & 24.43 & (19.31) & 20.77 & (8.21) & 0.033 \\
\hline Total cholesterol, $\mathrm{mg} / \mathrm{dL}$ & 203.89 & (38.73) & 193.24 & $(38.55)$ & 196.31 & (43.52) & 0.310 \\
\hline $\mathrm{HDL}, \mathrm{mg} / \mathrm{dL}$ & 45.93 & $(8.61)$ & 47.88 & $(7.62)$ & 47.68 & $(7.41)$ & 0.354 \\
\hline $\mathrm{LDL}, \mathrm{mg} / \mathrm{dL}$ & 127.85 & (29.85) & 114.58 & (31.46) & 122.35 & (33.88) & 0.067 \\
\hline Triglycerides, $\mathrm{mg} / \mathrm{dL}$ & 145.18 & $(74.20)$ & 159.29 & (142.19) & 131.62 & $(65.36)$ & 0.503 \\
\hline Vitamin B12, ng/L & 378.33 & $(180.80)$ & 275.35 & (124.66) & 319.46 & (130.35) & 0.001 \\
\hline $\mathrm{TSH}, \mu \mathrm{IU} / \mathrm{L}$ & 1.95 & $(2.06)$ & 2.00 & $(1.87)$ & 1.46 & (1.24) & 0.451 \\
\hline Phosphorus, mg/dL & 3.66 & $(0.73)$ & 3.46 & $(0.72)$ & 3.25 & $(0.92)$ & 0.052 \\
\hline $\mathrm{CRP}, \mathrm{mg} / \mathrm{L}$ & 3.73 & $(6.95)$ & 3.22 & (2.99) & 6.45 & $(9.82)$ & 0.046 \\
\hline ESR, mm & 12.15 & $(8.62)$ & 14.94 & (9.29) & 16.85 & (9.11) & 0.041 \\
\hline Female $\mathrm{n}, \%$ & 45 & (57) & 32 & $(65)$ & 21 & (81) & \\
\hline Male n, \% & 34 & (43) & 17 & (35) & 5 & (19) & \\
\hline
\end{tabular}

Values are expressed as $\mathrm{n}(\%)$ and mean \pm SD. BMI, body mass index; WBC, white blood cell; AST, aspartate aminotransferase; ALT, alanine aminotransferase; HDL, high density lipoprotein; LDL, low density lipoprotein; TSH, thyroid-stimulating hormone; CRP, C-reactive protein; VDBP, vitamin D binding protein; VDR, vitamin D receptor.

Table 3: Multinomial logistic regression analysis of variables that may be associated with IBS.

\begin{tabular}{|c|c|c|c|c|c|}
\hline \multirow[t]{2}{*}{ IBS types and control group ${ }^{a}$} & \multirow[t]{2}{*}{ B } & \multirow[t]{2}{*}{ Sig. } & \multirow[t]{2}{*}{ O.R. } & \multicolumn{2}{|c|}{$95 \% \mathrm{Cl}$ for $0 . \mathrm{R}$. } \\
\hline & & & & Lower bound & Upper bound \\
\hline \multicolumn{6}{|l|}{ Constipation } \\
\hline Intercept & -3.062 & 0.092 & & & \\
\hline Vitamin B12, ng/L & -0.004 & 0.018 & 0.996 & 0.992 & 0.999 \\
\hline ALT, IU/L & 0.060 & 0.008 & 1.062 & 1.016 & 1.110 \\
\hline VDBP, ng/mL & 0.146 & $<0.001$ & 1.157 & 1.066 & 1.256 \\
\hline 25-OH-vitamin D, ng/mL & -0.107 & $<0.001$ & 0.899 & 0.861 & 0.939 \\
\hline $\mathrm{CRP}, \mathrm{mg} / \mathrm{L}$ & -0.039 & 0.469 & 0.962 & 0.865 & 1.069 \\
\hline \multicolumn{6}{|l|}{ Other types } \\
\hline Intercept & -7.006 & 0.005 & & & \\
\hline Vitamin B12, ng/L & -0.001 & 0.665 & 0.999 & 0.996 & 1.003 \\
\hline ALT, IU/L & 0.041 & 0.120 & 1.042 & 0.989 & 1.097 \\
\hline VDBP, ng/mL & 0.208 & $<0.001$ & 1.231 & 1.105 & 1.373 \\
\hline 25-OH-vitamin D, ng/mL & -0.128 & $<0.001$ & 0.880 & 0.833 & 0.930 \\
\hline $\mathrm{CRP}, \mathrm{mg} / \mathrm{L}$ & 0.073 & 0.036 & 1.076 & 1.005 & 1.151 \\
\hline
\end{tabular}

${ }^{\mathrm{a}}$ The reference category is: Control Group. Nagelkerke R Square=0.531. Independent variables: Gender (dummy variable); age; BMI, body mass index; WBC, white blood cell; Vitamin B12; Vitamin D; VDBP, vitamin D binding protein; VDR, vitamin D receptor; ALT, alanine aminotransferase; LDL, low density lipoprotein; Phosphorus; CRP, C-reactive protein; ESR, erythrocyte sedimentation rate. 


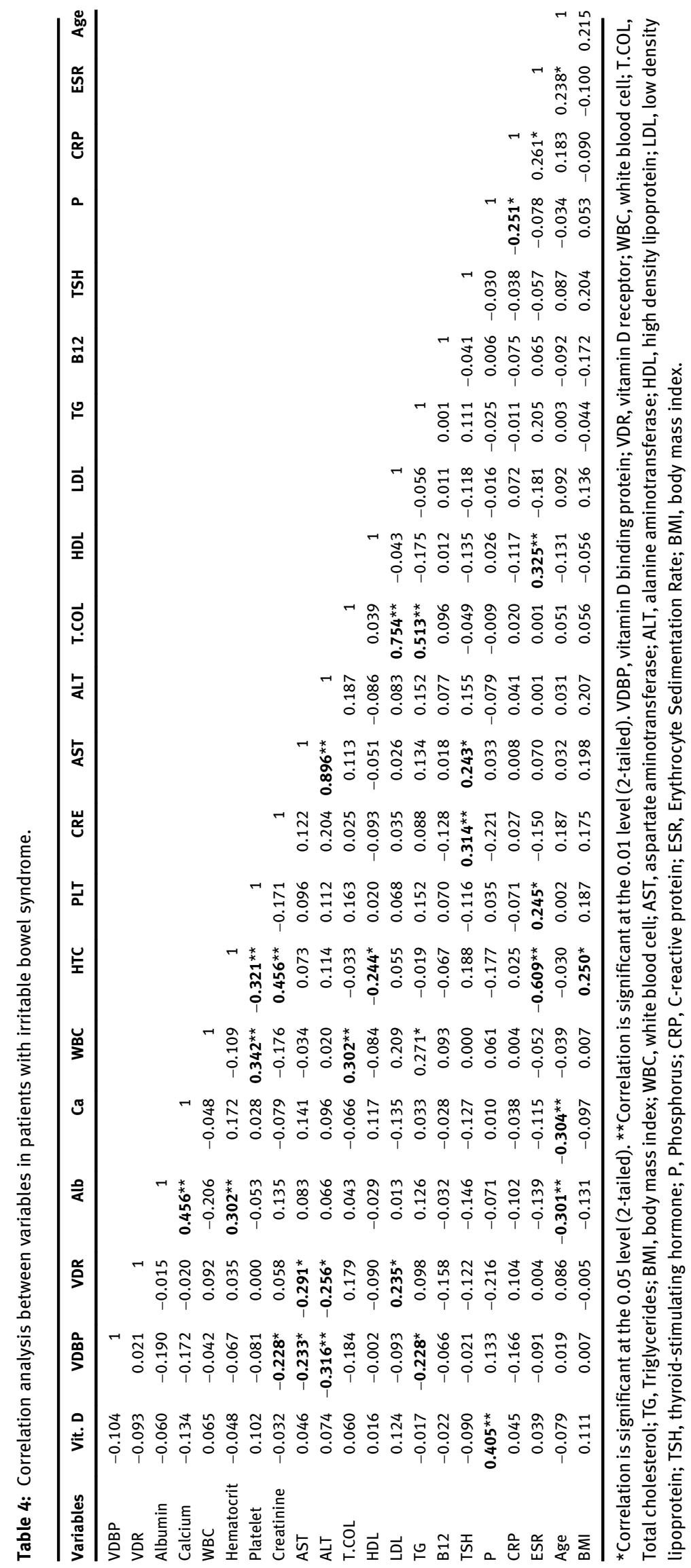




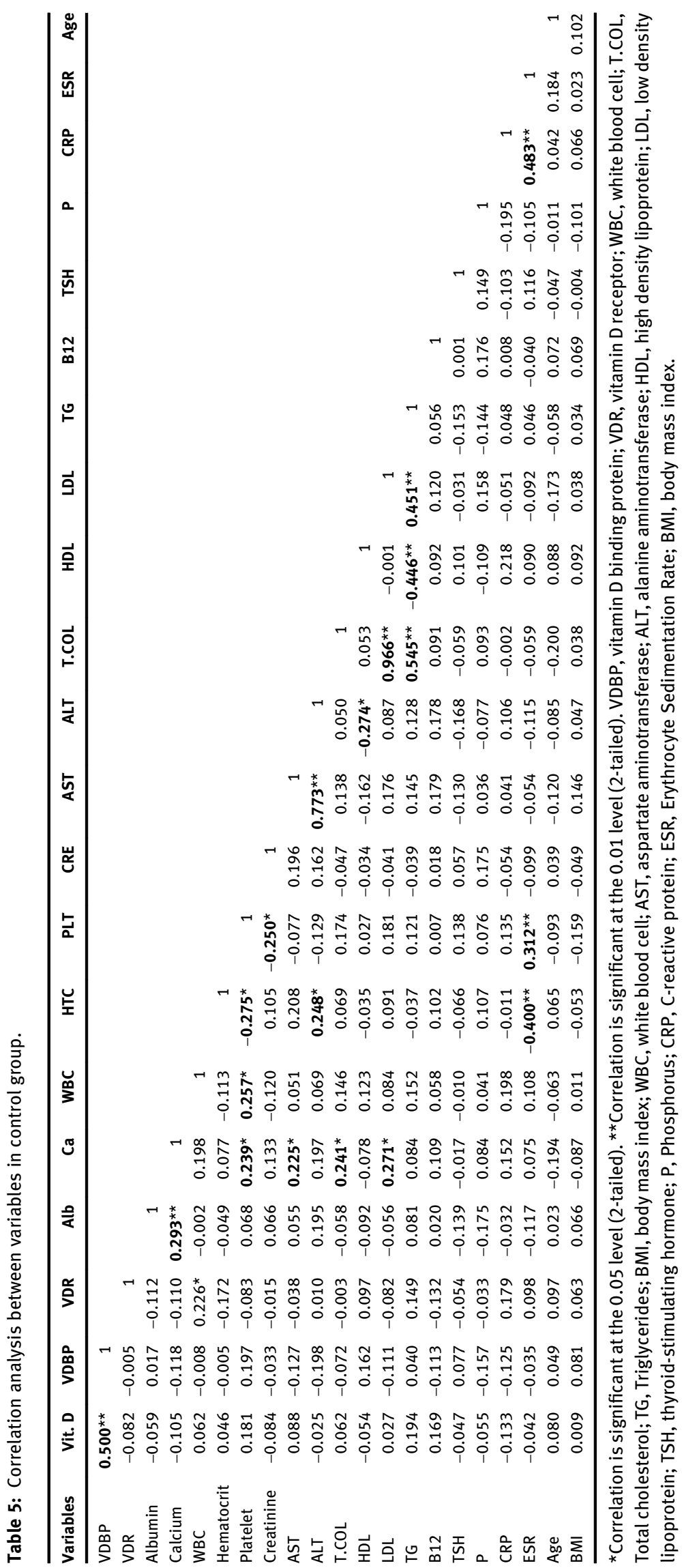


was detected that IL-6 level, a pro-inflammatory cytokine, is significantly higher in IBS-D compared to control [19]. In our study; serum ESR and CRP, markers of inflammation, were found to be higher in individuals with IBS, especially those with IBS-D than in non-IBS subjects. In multivariate regression analysis, only VDBP as an inflammation marker in IBS-C and both VDBP and CRP in other types of IBS were found to be significant and disease-related parameters. On the contrary, ESR lost its significance in regression analysis.

VDBP acts as a carrier for various ligands and plays a role in regulating immune and inflammatory processes such as activation of complement $\mathrm{C} 5$ system, chemotactic cofactor function, coactivating macrophages and binding to many immune cell surfaces $[10,11]$. Vitamin D itself or any of the vitamin $D$ metabolites do not act as a regulator in the production of VDBP [22]. VDBP levels in the blood are constant. During the inflammatory acute phase response, VDBP levels are slightly increased due to inflammatory cytokines stimulating hepatic transcription of VDBP [23, 24]. Clinical studies show that VDBP is a positive acute phase protein whose synthesis in the liver can be upregulated by pro-inflammatory cytokines such as IL-6 [25]. The fact that VDBP has diverse functions and its relationship with vitamin D levels indicates the potential importance of VDBP as a novel marker in a range of inflammatory and autoimmune diseases. Variability of VDBP concentrations in physiological fluids can provide useful information about the functioning of certain organs [15]. For example, sputum VDBP levels were found to be significantly higher in vitamin $\mathrm{D}$ deficient patients with bronchiectasis and have been associated with increased airway inflammation [26]. Elevated sputum VDBP levels have been associated with increased macrophage activation in patients with alpha-1-antitrypsin deficiency [27]. High levels of VDBP in the cerebrospinal fluid of patients with stable multiple sclerosis and patients with secondary progressive multiple sclerosis have been detected [28, 29]. Also, high expression of VDBP has been found in the serum and fresh thrombotic plaques of patients with ST elevation myocardial infarction [30]. In addition, altered levels of VDBP were detected in tuberculosis, diabetes mellitus type 1 , sepsis and cystic fibrosis [31-34]. In our study, we showed that VDBP is higher in IBS patients and is an important biochemical parameter associated with all IBS subtypes. Considering that IBS is a disease with low-grade inflammation; increased VDBP levels detected in IBS patients may be a result of the acute phase response due to inflammation.

Based on the knowledge that there is a relationship between low vitamin $\mathrm{D}$ levels and inflammatory diseases; we hypothesized that as Vitamin D levels decrease in IBS patients, VDBP levels may increase due to inflammation. When we look at the correlation analysis results; we found that there was a significant positive correlation between vitamin $\mathrm{D}$ and VDBP in healthy individuals $(\mathrm{r}=0.5$, $\mathrm{p}<0.001)$. In other words, as VDBP increased, the vitamin D levels increased in healthy individuals. However, no significant correlation was detected between vitamin $\mathrm{D}$ and VDBP levels in IBS patients. On the other hand, we considered it important that the correlation between vitamin D and VDBP in healthy individuals was not detected in IBS patients, as it demonstrated a relationship between IBS and VDBP.

The vitamin D receptor (VDR) found in the nuclei of various cells plays a very important role in the innate immune response. Vitamin D demonstrates immunomodulatory functions by binding to exogenous VDR on activated immune cells such as macrophages, dendritic cells, $\mathrm{T}$ and $\mathrm{B}$ lymphocytes [35]. It was thought that the higher VDR levels in the patient group in our study may be due to the upregulation of VDR. It is likely that the upregulation of VDR occurs as a negative feedback mechanism to control possible overreactions of the immune system [35].

The IBS-C subtype usually accounts for over a third of the IBS diagnosed in the population [36]. In our study similar to the literature, the majority of IBS patients were those with IBS-C. Also, lack of vitamin B12 which we consider as a result of the disease, was more common in IBS-C subtype compared to other IBS subtypes and controls. Recent findings have shown that small intestinal bacterial overgrowth can be seen in IBS with a frequency of $78-84 \%$ [37]. It is usually caused by the migration of colon flora with significantly higher bacterial load into the distal small intestine [38]. IBS patients are potentially disposed to small intestinal bacterial overgrowth due to delayed transit and irregular intestinal motility [38]. Vitamin B12 deficiency may develop in patients as a common complication of bacterial overgrowth [38]. Therefore, we think that the lower vitamin B12 levels we detected in IBS-C patients are the result of this process.

In conclusion, although there is no difference between the serum levels of vitamin D, VDBP and VDR among IBS subtypes, we have shown that VDBP is a significant biochemical parameter associated with all IBS subtypes and vitamin B12 levels are lower in patients with IBS-C and inflammatory biomarkers are particularly higher in the IBS-D subtype. Our shortcoming is that our study was not performed with a large patient population. Larger population studies are needed to clarify the differences in etiopathogenesis among IBS subtypes. 
Research funding: This work has been supported by Yozgat Bozok University Scientific Research Projects Coordination Unit under grant number: 6602a-TF/18-145.

Author contributions: All authors have accepted responsibility for the entire content of this manuscript and approved its submission.

Competing interests: The authors declare that there is no conflict of interest.

Çıkar çatışması: Yazarlar çıkar çatışması olmadığını beyan eder.

\section{References}

1. Drossman DA. Functional gastrointestinal disorders: history, pathophysiology, clinical features and Rome IV. Gastroenterology 2016;150:1262-79.

2. Lovell RM, Ford AC. Global prevalence of and risk factors for irritable bowel syndrome:a meta-analysis. Clin Gastroenterol Hepatol 2012;10:712-21.

3. Mearin F, Lacy BE, Chang L, Chey WD, Lembo AJ, Simren M, et al. Bowel disorders. Gastroenterology 2016;150:1393-407.

4. Ford AC, Talley NJ. Irritable bowel syndrome. BMJ 2012;345:37-42.

5. Bercik P, Verdu EF, Collins SM. Is irritable bowel syndrome a lowgrade inflammatory bowel disease? Gastroenterol Clin N Am 2005;34:235-45.

6. Lacy BE, Patel NK. Rome criteria and a diagnostic approach to irritable bowel syndrome. J Clin Med 2017;6:99.

7. Tazzyman S, Richards N, Trueman AR, Evans AL, Grant VA, Garaiova I, et al. Vitamin $D$ associates with improved quality of life in participants with irritable bowel syndrome: outcomes from a pilot trial. BMJ Open Gastroenterol 2015;2:e000052.

8. Abbasnezhad A, Amani R, Hajiani E, Alavinejad P, Cheraghian B, Ghadiri A. Effect of vitamin D on gastrointestinal symptoms and health-related quality of life in irritable bowel syndrome patients: a randomized double-blind clinical trial. Neuro Gastroenterol Motil 2016;28:1533-44.

9. Cantorna MT, Mahon BD. D-hormone and the immune system. J Rheumatol Suppl 2005;76:11-20.

10. Speeckaert M, Huang G, Delanghe JR, Taes YE. Biological and clinical aspects of the vitamin D binding protein (Gc-globulin) and its polymorphism. Clin Chim Acta 2006;372:33-42.

11. White $P$, Cooke N. The multifunctional properties and characteristics of vitamin D-binding protein. Trends Endocrinol Metabol 2000;11:320-7.

12. Haussler MR, Whitfield GK, Kaneko I, Haussler CA, Hsieh D, Hsieh $J$, et al. Molecular mechanisms of vitamin D action. Calcif Tissue Int 2013;92:77-98.

13. Kong J, Zhang Z, Musch MW, Ning G, Sun J, Hart J, et al. Novel role of the vitamin $D$ receptor in maintaining the integrity of the intestinal mucosal barrier. Am J Physiol Gastrointest Liver Physiol 2008;294:208-16.

14. Li YC, Chen Y, Du J. Critical roles of intestinal epithelial vitamin D receptor signaling in controlling gut mucosal inflammation. J Steroid Biochem Mol Biol 2015;148:179-83.

15. Lisowska-Myjak B, Jóźwiak-Kisielewska A, Łukaszkiewicz J, Skarżyńska E. Vitamin D-binding protein as a biomarker to confirm specific clinical diagnoses. Expert Rev Mol Diagn 2020; 20:49-56.

16. Moayyedi P, Mearin F, Azpiroz F, Andresen V, Barbara G, Corsetti $M$, et al. Irritable bowel syndrome diagnosis and management: a simplified algorithm for clinical practice. United European Gastroenterol J 2017;5:773-88.

17. Self MM, Czyzewski DI, Chumpitazi BP, Weidler EM, Shulman RJ. Subtypes of irritable bowel syndrome in children and adolescents. Clin Gastroenterol Hepatol 2014;12:1468-73.

18. Sprake EF, Grant VA, Corfe BM. Vitamin D3 as a novel treatment for irritable bowel syndrome: single case leads to critical analysis of patient-centred data. Case Rep 2012;2012:bcr-2012-007223. https://doi.org/10.1136/bcr-2012-007223.

19. Rana SV, Sharma S, Sinha SK, Parsad KK, Malik A, Singh K. Proinflammatory and anti-inflammatory cytokine response in diarrhoea-predominant irritable bowel syndrome patients. Trop Gastroenterol 2012;33:251-6.

20. Holtmann GJ, Ford AC, Talley NJ. Pathophysiology of irritable bowel syndrome. Lancet 2016;1:133-46.

21. Hauser G, Tkalcic M, Pletikosic S, Grabar N, Stimac D. Erythrocyte sedimentation rate - possible role in determining the existence of the low grade inflammation in irritable bowel syndrome patients. Med Hypotheses 2012;78:818-20.

22. Bjorkhem-Bergman L, Torefalk E, Ekstrom L, Bergman P. Vitamin $D$ binding protein is not affected by high-dose vitamin $D$ supplementation: a post hoc analysis of a randomised, placebocontrolled study. BMC Res Notes 2018;11:619.

23. Kew RR. The vitamin $D$ binding protein and inflammatory injury: a mediator or sentinel of tissue damage? Front Endocrinol 2019;10: 470.

24. White $P$, Cooke N. The multifunctional properties and characteristics of vitamin D-binding protein. Trends Endocrinol Metabol 2000;11:320-7.

25. Guha C, Osawa M, Werner PA, Galbraith RM, Paddock GV. Regulation of human Gc (vitamin D-binding) protein levels: hormonal and cytokine control of gene expression in vitro. Hepatology 1995;21:1675-81.

26. Chalmers JD, McHugh BJ, Docherty C, Govan JRW, Hill AT. Vitamin-D deficiency is associated with chronic bacterial colonisation and disease severity in bronchiectasis. Thorax 2013;68:39-47.

27. Wood AM, Bassford C, Webster D, Newby P, Rajesh P, Stockley RA, et al. Vitamin D-binding protein contributes to COPD by activation of alveolar macrophages. Thorax 2011;66:205-10.

28. Rinaldi AO, Sanseverino I, Purificato C, Cortese A, Mechelli R, Francisci S, et al. Increased circulating levels of vitamin $D$ binding protein in MS patients. Toxins 2015;7:129-37.

29. Yang M, Qin Z, Zhu Y, Li Y, Qin Y, Jing Y, et al. Vitamin D-binding protein in cerebrospinal fluid is associated with multiple sclerosis progression. Mol Neurobiol 2013;47:946-56.

30. Gasparri C, Curcio A, Torella D, Gaspari M, Celi V, Salituri F, et al. Proteomics reveals high levels of vitamin $D$ binding protein in myocardial infarction. Front Biosci (Elite Ed) 2010;2:796-804.

31. Owolabi O, Agbla S, Owiafe P, Donkor S, Togun T, Sillah AK, et al. Elevated serum 25-hydroxy $(\mathrm{OH})$ vitamin D levels are associated with risk of TB progression in Gambian adults. Tuberculosis 2016; 98:86-91.

32. Blanton D, Han Z, Bierschenk L, Linga-Reddy MV, Wang H, Clare-Salzler M, et al. Reduced serum vitamin D-binding 
protein levels are associated with type 1 diabetes. Diabetes 2011;60:2566-70.

33. Jeng L, Yamshchikov AV, Judd SE, Blumberg HM, Martin GS, Ziegler TR, et al. Alterations in vitamin D status and anti-microbial peptide levels in patients in the intensive care unit with sepsis. J Transl Med 2009;7:28.

34. Speeckaert MM, Wehlou C, Vandewalle S, Taes YE, Robberecht E, Delanghe JR. Vitamin D binding protein, a new nutritional marker in cystic fibrosis patients. Clin Chem Lab Med 2008;46:365-70.

35. Kongsbak M, Levring TB, Geisler C, von Essen MR. The vitamin d receptor and T cell function. Front Immunol 2013;4:148.
36. Chandar AK. Diagnosis and treatment of irritable bowel syndrome with predominant constipation in the primary-care setting: focus on linaclotide. Int J Gen Med 2017;10:385-93.

37. Nucera G, Gabrielli M, Lupascu A, Lauritano EC, Santoliquido A, Cremonini $F$, et al. Abnormal breath tests to lactose, fructose and sorbitol in irritable bowel syndrome may be explained by small intestinal bacterial overgrowth. Aliment Pharmacol Ther 2005;21: 1391-5.

38. Dukowicz AC, Lacy BE, Levine GM. Small intestinal bacterial overgrowth: a comprehensive review. Gastroenterol Hepatol 2007;3:112-22. 